\title{
The potential of design to build freedoms: a case study of design for sustainability in a scavengers association
}

\author{
Mariana Fonseca Braga ${ }^{1}$, Eduardo Romeiro Filho ${ }^{2 *}$ \\ ${ }_{1}^{1}$ ImaginationLancaster, Lancaster Institute for the Contemporary Arts (LICA), Lancaster University, United Kingdom \\ ${ }^{2}$ Laboratório Integrado de Design e Engenharia do Produto, Departamento de Engenharia de Produção, Universidade Federal de Minas Gerais - UFMG, Belo
} Horizonte, MG, Brasil

\begin{abstract}
This paper presents a case study conducted at ASMARE (Paper, Cardboard and Reusable Material Collectors Association), in Belo Horizonte, Brazil. ASMARE is a "scavengers" association that screens recyclable waste to sell it to recycling companies. The purpose of this study is to analyse the potential of the current practices of one sector of this organization, the Carpentry Factory, for sustainability. The Carpentry Factory enables workers to design and manufacture products from reused and recycled materials. This research demonstrated that fostering creative, design- and art-related capabilities can improve the results in terms of profitability and sustainability, adding value to the organization activities and outcomes, hence to the work of ASMARE members.
\end{abstract}

Keywords: product design, ASMARE carpentry factory, sustainability.

\section{Introduction}

This study aims to understand the potential of the ASMARE carpentry factory activities to increase the value of their work, and for sustainability considering the triple bottom line perspective (economic, social and environmental sustainability). In order to achieve this aim, we focus on understanding two mainstreams of production in the ASMARE carpentry factory: one based on the ecoplaca (recycled board), and another one based on the upcycle of second-hand furniture.

There is little research on the importance of the value of work and related activities for sustainability although it is recognised as a key factor in sustainability. It is also known that the urgency of economic resources in a context of vulnerability strongly influences the decisions regarding sustainability/unsustainability. The urgent need for economic resources, for instance, in the case of low-income informal workers, is usually related to other socioeconomic disadvantages such low level of formal education and/or access to a low quality of education or lack of access to education among others.

ASMARE, the "Paper, Cardboard and Reusable Material Collectors Association" in Belo Horizonte (Minas Gerais, Brazil) develops several complementary activities that aim to contribute to social inclusion. These activities are carried out in different locations, such as two cultural centres and restaurants, a recycling centre dedicated to the waste of building sites, a crafts factory that reuses waste materials and a carpentry factory (Gonçalves et al., 2008). All these activities serve as a way of social inclusion and training for workers from social risk groups, such as low-income informal workers, unemployed people, young people without formal education, the elderly, or individuals that are usually marginalised by society due to their low social status, lack of formal education or professional training, or drug-related problems (Cannon et al., 2020; Santos, 2014). Initially, the Carpentry Factory was created to provide scavengers with the maintenance work of the wood carts that are built and used by scavengers, and to help them learn new skills (Figure 1).

A new material made up of recycled post-consumption long-life packaging was introduced to the carpentry factory, the "ecoplaca" (Teodoro, 2011). The "ecoplaca" (ecoboard) is also made from industrial waste that comes from, i.e., the toothpaste tube's production. In the ASMARE carpentry factory, the production of dustbins made up of "ecoplacas" is gradually replacing the upcycle of furniture from reusable materials. The civil society, institutions and organizations donate these reusable materials generally in the form of second-hand furniture. These both productions, the manufacture of dustbins composed of "ecoplacas" and the upcycle of furniture from donated reusable materials, affect the activities in the carpentry in different ways. 


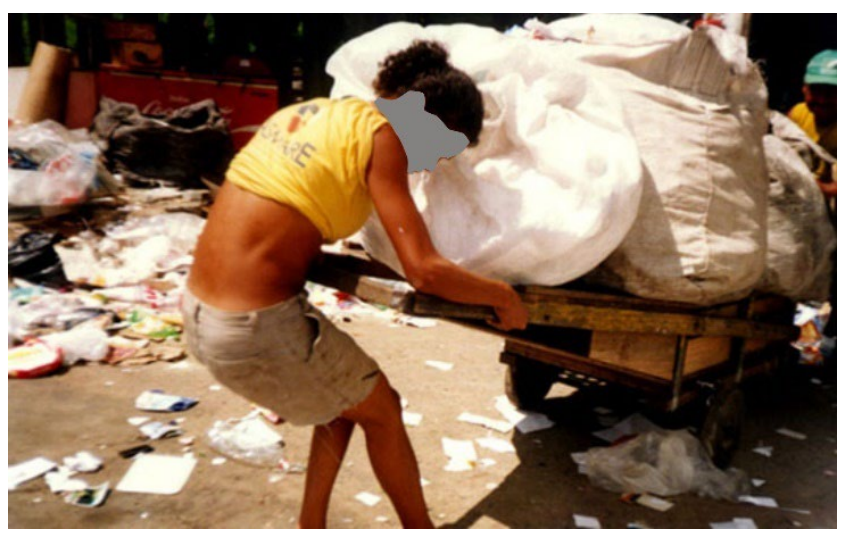

Figure 1. Scavenger and one model of wood cart used by scavengers in Belo Horizonte.

Currently, the production of dustbins made up of ecoplacas increases due to their profitability and to the standardized manufacturing processes. The ecoplaca boards come from factories from Sao Paulo $(630 \mathrm{Km}$ from Belo Horizonte). They are stored in the carpentry factory, occupying the area that was previously utilized to store reusable materials. The manufacture of dustbins is conducted through repetitive processes (creativity deployment is not explored) characterized by division of tasks that require very low training. The production of dustbins is based on one pre-set project proposed by external collaborators. This predictable manufacture cycle is gradually replacing the upcycle of furniture from second-hand materials, which is considered a more complex and specialized activity requiring creative skills employment and design effort to usually produce one product from that project. Thus, each object involves a different project attempt.

\section{Literature review}

Understanding the garbage as a resource is an essential principle for sustainability (Calvo-Porral, 2020; Asprilla-Perea et al., 2020). Besides, other aspects are also recognised in the literature. They are related to the consumption behaviour and other socio-economic determinants. Global consumption is very high, and it is widely reported that $20 \%$ of the world population consumes about $80 \%$ of resources (Manzini, 2007; Tukker et al., 2008). There are undeniably connections between social inequality, justice, democracy and their influence on the exploitation of resources and consequent environmental impacts (Comissão Mundial Sobre Meio Ambiente e Desenvolvimento, 1991; Commission on Sustainable Development, 1992; World Summit on Sustainable Development, 2002). We understand that the value of work is a fundamental factor in achieving social sustainability and there is little research on this (Petrina, 2000; Walker \& Dorsa, 2001; Jeswiet \& Hauschild, 2005).

The traditional mass production and the conventional priorities of companies (as profit improvement by a continuous growing revenue process) are incompatible with sustainability (Topcua et al., 2020). The term "sustainability" refers to the thought that human activities should take into consideration environmental and ethical issues in addition to economic ones, and the question in the design field is " [...] how functional objects can be designed and created in a consistent manner with sustainability principles" (Walker, 2002). The conventional concept of ecodesign is perceived as tied to the issue of competitiveness of the product in the market (Xavier et al., 2017). However, sustainability involves issues that are beyond this narrow view. Reducing environmental impacts is a "two way street" that call for changes not only in the production and value chains, but also in the behaviour and lifestyle of Western societies' consumers (Manzini \& Vezzoli, 2005; Manzini, 2007; Petrina, 2000; Tukker et al., 2008; Zafarmand et al., 2003). About $70 \%$ to $80 \%$ of environmental impacts on society are caused by mobility (air and ground transportation), food (meat followed by other types of food), energy use in and around the home (heating, cooling and energy spent with products), home construction and demolition (Tukker et al., 2008). Ecodesign is traditionally related to the reduction of environmental impacts, and its approach alone, as above-mentioned, does not lead to sustainability. We need ecocentric approaches to product development that involve a drastic reduction in the levels of production and consumption (Manzini, 2007). It is necessary to understand the sociological nature of sustainability problems regarding culture production and consumption as well as to break the cycle of wastefulness of untenable Western cultures which can be summarised as: production - consumption - garbage (Petrina, 2000).

The result of consumption or post-consumer products discard is only a small part of the problem, because the product itself contains on average only $5 \%$ of the raw materials involved in manufacturing and delivering it (McDonough \& Braungart, 2002). Thus, we must rethink the design and production in order to erase the concept of garbage (Dogan \& Walker, 2003). This is consonant with the industrial ecology proposal, recently known as 
the circular economy approach, in which the waste of one company is a resource in another one, constituting a "closed loop". It also corroborates environmental approaches which aim at adding value to waste, initially valueless, through recycling, upcycling, or reuse, being opposed to a hygienist approach or an end-of-pipe approach that is based on the principle of waste collection and treatment.

We need to move beyond the ecodesign approach to design (e.g. reduction of products' materials, Design for Manufacture and Assembly [DfMA]) and seriously consider socio-cultural problems related to education, social inequalities and lifestyle. Advances in ecodesign and environmental approaches are significant, whereas, with regard to sustainability, they seem little (Walker \& Dorsa, 2001). In that sense, "not every proposal for environmental improvement is sustainable" (Borchardt et al., 2008).

Countries at different stages of economic development need sustainable consumption and production policies suited to their specific contexts, in other words, different policies. Crul \& Diehl (2006) point out sustainable principles for developing economies. For example, countries of the "base of the pyramid" (according to Prahalad, 2005 , the term "base of the pyramid" refers to the base of the economic pyramid, where people who live on incomes below $\$ 2.00$ per day are) have an initial goal of establishing a foundation for a sustainable and equitable growth and poverty eradication (Tukker et al., 2008).

\section{Methodology}

This research used the single case study strategy (Yin, 1994) and was built upon triangulation of methods (Voss et al., 2002; Yin, 1994) from Work Ergonomic Analysis (Wisner, 1987; Guérin et al., 1991) and action research (Thiollent, 1983, 1985, 2007), namely non-directive interview, participant observation and verbalizations of the actors at different times (during design and manufacturing activities and breaks) conducted throughout one year in the work environment. These methods contributed to extensive fieldwork and first-hand data collection. In addition, initiatives were carried out in collaboration with members of the carpentry factory and other external actors (as costumers, ASMARE managers, partners and scavengers). Primary data were collected from internal and external actors. The research design involved interaction between different phases (Eisenhardt, 1989).

The non-directive interviews were adapted from guidelines established in Ergonomics (Wisner, 1987; Guérin et al., 1991); in action research (Coughlan \& Coghlan, 2002; Checkland, 1981; Thiollent, 1983, 1985, 2007); in the psychosocial (Sorokin, 1964) and ethnography (Malinowski, 1976) fields. We sought to (1) capture the actors' perspectives, using the 'relaunch' of questions in order to obtain a perception as close as possible to the actors about the work situations; (2) distinguish in the records the perception of the actor from the perception of the researcher (Malinowski, 1976) and (4) build validity through the triangulation of methods (Yin, 1994; Voss et al., 2002).

The combination of methods aimed to capture the design and manufacturing activities at work from the perspectives of the actors and to provide grounds for the analysis of the relationship between these work activities and sustainability through the triple bottom line lens.

Designers learn conventionally which is convenient to industrial situations, while dealing in other contexts requires a specific approach to understanding the universe of the other (e.g. the work of artisans and people at social risk - Freitas, 2011; Freitas \& Romeiro Filho, 2005) in Brazil despite (1) the global expansion of the design field and specialisations (e.g. Product-Service Systems, Design for Policy, Service Design, Strategic Design, Design Management etc.) (Julier, 2017), (2) the recognition of the importance of situated design practices, and (3) although design awareness and understanding (hence potential) vary across the country (Fonseca Braga, 2019). Therefore, local (geographical, social, cultural, political etc.) conditions, resources and circumstances, including prior experience and tacit knowledge, are usually neglected. In seeking to understand the other, the designer can go "beyond the product". The nature of design knowledge is closely related to its practice (Brown, 2009; Cross, 2001; D'Ippolito, 2014; D'Ippolito et al., 2014) and design skills are generally gained in a 'learning by doing' approach (e.g. Brown, 2002, 2009). Thus, understanding the "design thinking" logic of this social group means contributing not only to the product, but to how design can contribute to the participation of scavengers in "methodological" and educational improvement. This issue is beyond the creation of a product, and is concerned with how design can add value to their processes and products, fostering skills that enable social inclusion through learning at work.

We propose a design process that emphasizes teamwork and the development of design skills, using design techniques in an "organic intellectual" approach (Romeiro Filho, 2013). Such approach has the potential to consolidate and spread the skills that workers can develop designing and manufacturing products from reusable materials. A sustainable approach has to question the value of work because it is a fundamental matter for social and economic sustainability, in this case consonant with the environmental one. 


\section{Results}

\subsection{The ASMARE carpentry factory activities}

The carpentry factory is part of the ASMARE. It is one of its craft workshops used to upcycle furniture and to repair the wood carts of scavengers. The carpentry factory was founded in 1994 and is located next to a warehouse for collection and screening (sorting) of recyclable materials. The initial goal of the carpentry factory creation was to contribute to the development of skills of young people and to providing maintenance of the wood carts. Over time, other activities were incorporated such as the repair and upcycle of furniture pieces and other objects.

There are several activities carried out in the ASMARE carpentry factory, among them:

- the production of dustbins (Figure 2),

- the production and maintenance of scavengers' carts,

- furniture and other materials upcycling (Figure 3),

- manufacture of tailored products associated with the use of ecoplaca and

- social projects involving local universities.

The carpentry has also the support of partners and collaborators for the development of products, especially product design, including concept development.

Another initiative is the collaboration with the Belo Horizonte Municipality which includes participation in socioeducational measures for young people who committed some infraction. They are trained by the group of scavengers through the support of apprentices and associates who participate in the activities of the carpentry factory.

One of the differentiator factors of the carpentry products in the furniture sector is the continuous demand for an "ecoproduct" (as categorized by the actors involved in the work). In this case, this means making products made up of recycled (such as ecoplaca) or reused material according to a customer demand and to the nature of activities in ASMARE. Ecoplaca boards are not produced by ASMARE. They are acquired from a manufacturer from São Paulo. In most cases, the customers already knew the ASMARE or acknowledged the work carried out there regarding the screening of recyclable materials. Some customers also cooperate in other ways such as donating recyclable materials.

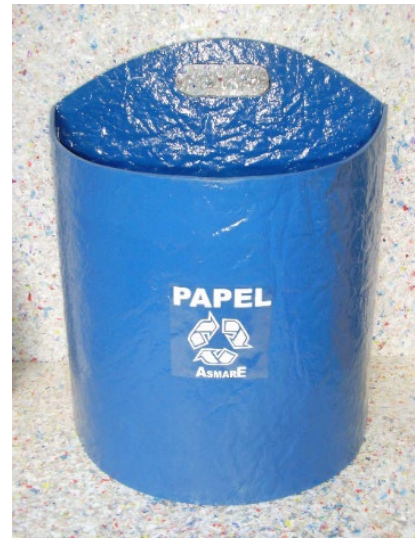

Figure 2. Dustbin manufactured in the carpentry factory.

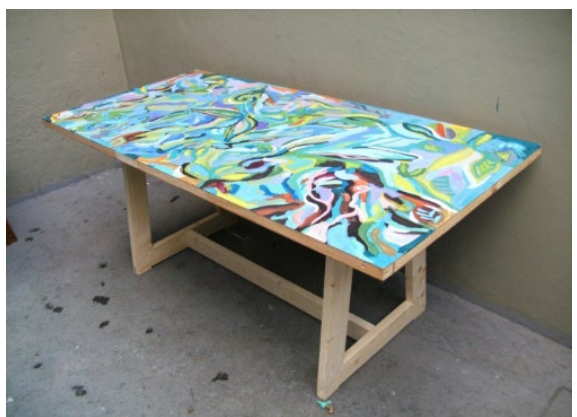

Figure 3. Table made up of reused material (wooden pallets and a door) manufactured in the ASMARES carpentry factory.

The workers who usually attended the carpentry factory on a regular basis during the research period were the Instructor, the Carpenter, Associates and Apprentices. The Instructor and the Carpenter are in charge of most 
decision-making in the carpentry. The internal organization of the carpentry is managed by the ASMARE administration, which evaluates and approves (or disapproves) the internal decisions. Associates do not receive salaries in ASMARE and the profit is shared by all partners, this also applies to those who participate in activities in the carpentry. The workers themselves manage their schedules considering also the activities related to the collection and screening of waste.

Most workers of this system are excluded from the formal labour market and search for alternatives for their income. They live in situations of social risk, characterized by exposure to violence, addictions, poor housing, diseases, low income to support the family among other factors. Some are able to integrate themselves into society, but there are still many social reintegration challenges. The level of formal education among the carpentry workers ranges from four to eleven years. Some of them have reading and writing difficulties although they have certificates attesting their formal level of education what indicates the low quality of education received.

The activities in the carpentry also rely on the manual skills that the actors develop throughout their experience at work. The Instructor and the Carpenter define the job and related activities as a "handmade work" due to its difference from industrial pattern of production, especially in the case of reuse of materials. The multiple functions performed by the workers are noticeable.

\subsection{Production process, equipment and materials}

Varied activities can be observed in the carpentry factory, from the production of customised products to the production of products based on the same project (see Figure 4). The latter is characterised by the division of tasks and the large-scale production, with less intervention from the factory floor in product development, except by the Carpenter and Instructor, who participate in the activities of design and manufacturing.

The main recycled material used in the production of products is known as "ecoplaca": it is a material composed of " $75 \%$ plastic (polyethylene), $23 \%$ aluminum, $2 \%$ cellulose fiber" that come from post-consumption long-life packages. The ecoplaca has variations such as "tube ecoplaca" made up of $75 \%$ aluminium, $25 \%$ of polyethylene which has a different finishing from those that have cellulosic fibre, moreover "tube ecoplaca" is made from industrial waste that comes from the toothpaste tube's production (Teodoro, 2011).

On the other hand, the resources employed to upcycle second-hand furniture and other materials come from:

- donated furniture (that, otherwise, would be discarded by previous owners),

- wood from pallets and crates,

- steel (and other metal leagues),

- PVC and acrylic.

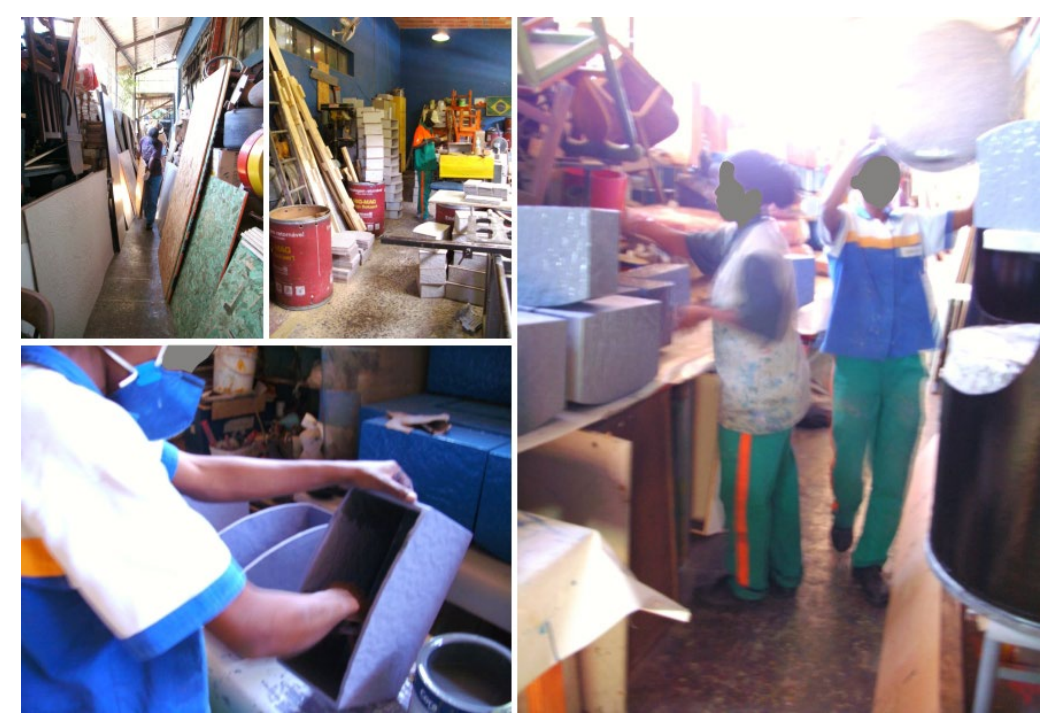

Figure 4. Some stages of dustbins' production processes.

In a complex process that involves the deployment of creative and decision-making competences, the Instructor and the Carpenter (sometimes together with other professionals as product designers, architects, internal designers, artists such as painters and sculptors) turn the demands for products made up of reused materials into products' sketches, and concept drafts with basic dimensions and prototypes (see Figure 5). These serve as the reference for production, which unfolds, through the Instructor's supervision. Most activities that are carried out by the Carpenter and other members concern manufacture (the Instructor also carries out 
manufacturing activities when necessary). In the case of the reuse of materials, identification and selection of the most appropriate materials to a project are required.
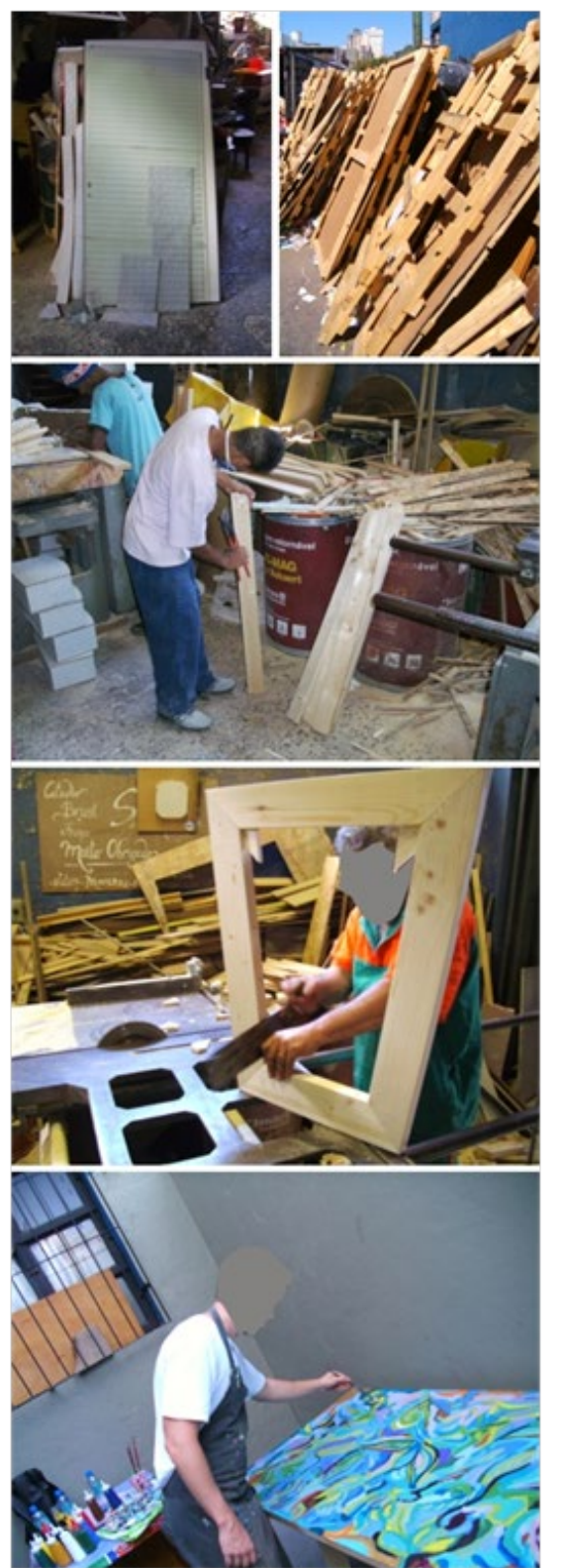

Figure 5. Some stages of the production process of a table made from second-hand donated materials.

\subsection{Product design, scale production and reuse}

The elements of product design in the carpentry's work vary according to their two production models explained in the previous section. When it comes to manufacturing a product from reused material, the creative effort is greater and can be observed in diverse stages of their design process. A single drawing works for one or few products depending on the availability of materials and on the flexibility of the adopted design. In contrast, the same design lasts for a longer time and may be reproduced in hundreds of product units with the use of recycled material, such as ecoplaca (a board with defined and standardised size and features). This facilitates a scale production by setting standards.

Design processes and methods are applied and identified in the carpentry factory, as follows:

1. Ideation through sketches;

2. Definitions of specifications such as dimensions, materials and finishing, and the assemblage of the product;

3. Mock-ups are built in alternative materials and in diverse scales; 
4. A manufacturing plan is made, and tests are conducted to check the feasibility and the performance of the product;

5. Finally, a prototype is made as a pilot for production processes.

The design and production processes utilizing second-hand donated furniture and materials involve a creative effort to develop a product concept and its new parts from a variety of heterogeneous and non-standardized materials, resulting in a more creative engagement with product design activities and requiring problem-solving skills in diverse stages of product development and production. That is, the choice of material is not just a choice that aims to decrease the environmental impacts.

On the one hand, the scale production (the case of the dustbin made up of ecoplaca) enables to manufacture more products. This may contribute to the carpentry economic sustainability. On the other hand, value-added products made from reused materials can pay off the more complex design and production processes.

\section{Economic, social and environmental sustainability in the carpentry factory}

Considering the economic aspect, the production of dustbins made of "ecoplaca" allows the sustainability of the ASMARE carpentry factory, because it provides the working capital for production, which is essential to meet the demands and pay those involved in the carpentry work on a short-term basis. In this sense, the dustbins' manufacture is more sustainable than the production based on the reuse of materials due to their marked variability and to the qualifications required for the intense creative effort to 'recreate' objects from second-hand materials with pre-set and different shapes and characteristics. Furthermore, the demand for products made up of reused materials tends to be more unpredictable according to the Instructor.

However, the added value of a product made of reused materials can offer higher profit margins than an ecoplaca dustbin. For example, the table (see Figure 3) production spent the equivalent of $\$ 34.00$ on the cost of cleaning the woods (which were donated) and of finishing materials, plus about $\$ 8.50$ regarding materials and tools to paint the worktop art. The price of the product to an end consumer, considering the worktop art square meters, the product design, the cleaning of the woods and the cost of other materials and tools for production would be about $\$ 1,875.00$. That is, the profit of the table would be $\$ 1,832.50$ (that means just over $2 \%(\$ 42.5$ ) of $\$ 1,875.00$ were spent on production with the profit around $4,500 \%$ of the production cost). This profit can be considered as the cost of labour once the profit in the current system is shared by all ASMARE associates. In the dustbins (see Figure 2) case, based on the production discussed in this paper, the average profit was just over $92 \%$ of the cost for the production (including materials and tools).

Thus, the reuse of materials offers best potential to add value to the work with most rewarding activities. This possibility requires, from people involved, greater diversity of skills, including design and art-related ones. Postconsumer materials that are available to reuse are resources that could also be a source of working capital in the carpentry factory considering a strategic approach to their value creation. Another aspect is the need for knowledge of the actors themselves about the second-hand furniture pieces donated to the carpentry factory, among which are design classics, objects that are part of the Brazilian design history.

Regarding the social aspect, the reuse of materials fosters the acquisition of a greater diversity of skills in the workplace (although it requires more oversight and monitoring by the Instructor), enabling teamwork in diverse stages of product design with better opportunities for a more rewarding and creative work, properly human, different from the machines monotony and repetition. In contrast, in the production of dustbins, learning happens in smaller variety of skills, given the repetition of activities based on a scale production model, which is considered easier for the manufacturing and learning processes.

The formation of associates and trainees is a key aspect to be considered in the organization. There is not a formal training process in the carpentry. The experience and tacit knowledge are essential in the production processes, especially in the selection of materials from donated furniture. This expertise and some elements of product development processes are also identified in micro furniture companies in Brazil (Souza et al., 2019).

Moments of satisfaction were recognised among apprentices in an activity involving the product design and construction of small-scale mock-ups. Some workers have expressed greater interest in production from the reuse of materials than in the manufacture of dustbins. Those who prefer to work on the dustbins' production say that it is easy, and they know how to do it.

Environmental criteria are not a priority to working practices due to economic urgencies in the social context. It is noticed that, according to interviews' respondents, there is not a perceived distinction between the product that uses ecoplaca and the one which is made from reused materials; both are seen as beneficial in a socioenvironmental perspective. There are still several points of the ecoplaca production chain without any available information, such as regarding the reverse logistics of the cardboard, the specific cities where the post-consumer packages come from, taking into consideration the fact that ecoplaca boards' factories and collection sites are 
concentrated in the São Paulo state. The reuse of materials offers best environmental benefits in a qualitative analysis, because it is locally housed and contributes to the diversion of bulk of objects from Belo Horizonte landfills, introducing them into new cycles of value, contributing to a circular economy.

Therefore, in this case, the reuse of furniture and other materials can bring major benefits related to work improvement in the carpentry factory, providing more learning opportunities, and fostering the creative skills of those involved. These can contribute to building free subjects, able to express, reflect and argue their choices in a social dialogue. On the other hand, this process requires experience and training of the worker. Usually, the learning process of workers is mediated by personal relations and the opportunities to engage with internal (supervisor) and external (designers) actors, as well as the personal interest and motivation. In order to underpin the reuse of materials and the aforementioned advantages, we propose a "guiding" design process (Figure 6), which serves as a basis for upcycling. Part of this was already successfully implemented by the carpentry members during this research. Reused materials were classified and stored according to their possible product/furniture functions.

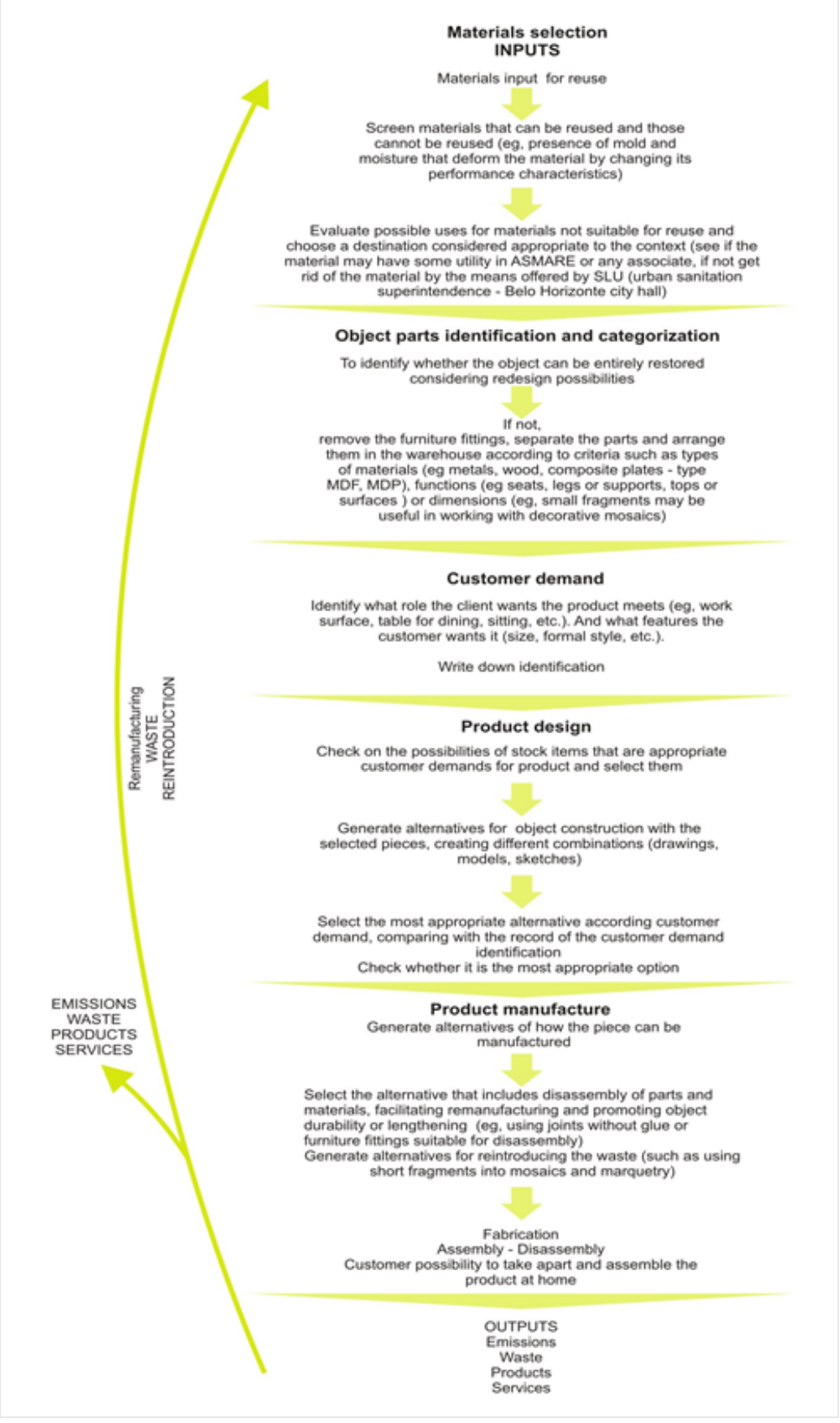

Figure 6. Methodological procedure proposed for product design. 


\section{Conclusion}

Social inequalities barely changed worldwide (Organisation for Economic Co-operation and Development, 2020). Institutional mechanisms contribute to perpetuating these inequalities (Acemoglu \& Robinson, 2012). The value of human work is a key factor in achieving sustainability although there is little research on the topic. This study showed that there is potential to increase the value of the work in the ASMARE carpentry factory by fostering creative, design- and art-related skills. The extent to which the rise in the value of work can lead to more sustainable futures in this context is still a limitation that should be addressed through pilot interdisciplinary training programmes along with future research.

Poorly qualified and low-value jobs, common in most least-, low- and middle-income countries, reduce the worker to the object, especially when there is not an improvement of living conditions, when there is urgency to obtain money for one-day feed, sometimes for the next meal as noticed throughout the fieldwork conducted. Design capabilities based on visual methods that do not rely on literacy have the potential to be learned by individuals regardless of their level of formal education. They are built closely related to their practice in a "learning by doing" process. Understanding better those situations in which design capabilities can play a role and improve living conditions of people exposed to social risk - socially marginalized - are still huge creative and pedagogical challenges for designers.

This paper is limited to learning through product design activities in the organization addressed in the case study. Design activities and skills can contribute to building reflective individuals who are able to explore and deploy better their creativity at work, acting upon their needs. We believe that, through such studies, design can expand its focus beyond "user-centered" or "human-centered" into design for "freedom" (Sen, 1999).

\section{Acknowledgements}

The authors thank the CAPES - Coordenação de Aperfeiçoamento de Pessoal de Nível Superior, for the financial support of this research, the ASMARE and all workers involved in this research for their collaboration and meaningful insights into their work in the carpentry factory.

\section{References}

Acemoglu, D., \& Robinson, J. A. (2012). Why nations fail: the origins of power, prosperity and poverty (1st ed.). New York: Crown.

Asprilla-Perea, J., Díaz-Puente, J. M., \& Martín-Fernández, S. (2020). Evaluation of wild foods for responsible human consumption and sustainable use of natural resources. Forests, 11(6), 687.

Borchardt, M., Poltosi, L. A. C., Sellitto, M. A., \& Pereira, G. M. (2008). Considerações sobre ecodesign: um estudo de caso na indústria eletrônica automotiva. Ambiente \& Sociedade, 11(2), 341-353.

Brown, T. (2002, June). Design thinking. Harvard Business Review, pp. 1-11.

Brown, T. (2009). Change by design: how design thinking transforms organizations and inspires innovation. New York: Harper Collins Publishers.

Calvo-Porral, C. (2020). Creating value from garbage: a marketing and circular economy strategy for sustainability. In G. Andraz, H. Carrasqueira, R. Pereira \& R. Baleiro (Eds.), Dynamic strategic thinking for improved competitiveness and performance. Hershey: IGI Global.

Cannon, M., Thorpe, J., \& Emili, S. (2020). ASMARE: informal waste workers engaging in municipal policy-making (Case Summary, No. 16). Brighton: IDS.

Checkland, P. B. (1981). Appendix 2: a workbook for starting systems studies. In P. B. Checkland (Ed.), Systems thinking, systems practice (pp. 294-297). Chichester: Wiley.

Comissão Mundial Sobre Meio Ambiente e Desenvolvimento - CMMD. (1991). Nosso futuro comum (2. ed.). Rio de Janeiro: Editora da Fundação Getúlio Vargas.

Commission on Sustainable Development - CSD. (1992, December). Agenda 21. The United Nations Programme of Action from Rio. Retrieved in 2019, June 23, from http://www.un.org/esa/dsd/agenda21/

Coughlan, P., \& Coghlan, D. (2002). Action research for operations management. International Journal of Operations \& Production Management, 22(2), 220-240.

Cross, N. (2001). Designerly ways of knowing: design discipline versus design science. Design Issues, 17(3), 49-55.

Crul, M. R. M., \& Diehl, J. C. (2006). Design for sustainability: a practical approach for developing economies. Delft: United Nations Environment Programme, Delft University of Technology, November. Retrieved in 2019, October 18, from http://www.unep.fr/scp/publications/details.asp?id=DTI/0826/PA

D'Ippolito, B. (2014). The importance of design for firms' competitiveness: a review of the literature. Technovation, 34(11), 716730. http://dx.doi.org/10.1016/j.technovation.2014.01.007.

D’Ippolito, B., Miozzo, M., \& Consoli, D. (2014). Knowledge systematisation, reconfiguration and the organisation of firms and industry: the case of design. Research Policy, 43(8), 1334-1352. http://dx.doi.org/10.1016/j.respol.2014.03.013. 
Dogan, C., \& Walker, S. (2003). The Best of Both: A Study of the Feasibility of Integrating Scales of Design and Production for Sustainable Products. The Journal of Sustainable Product Design, 3(3), 135-147.

Eisenhardt, K. M. (1989). Building theories from case study research. Academy of Management Review, 14(4), 532-550.

Fonseca Braga, M. (2019). Handling design support programmes complexity: an interpretative framework for barriers and drivers to introducing design innovation into MSMEs [PhD Thesis]. Department of Design, Politecnico di Milano, Milan.

Freitas, A. L. C. (2011). Design e artesanato: uma experiência de inserção da metodologia de projeto do produto. São Paulo: Blücher Acadêmico.

Freitas, A. L. C., \& Romeiro Filho, E. (2005). Ademically supported social work for the development of handicraft skills: case study: the Pitangaporã Project. Product: Management \& Development, 3, 87-91.

Gonçalves, J. A., Oliveira, F. G., \& Silva, D. (2008). Dezoito anos catando papel em Belo Horizonte. Estudos Avançados, 22(63), 231-238.

Guérin, F., Kerguelen, A., Laville, A., Duraffourg, J., \& Daniellou, F. (1991). Comprende le travail pour le transformer. Paris: Éditions de l'ANACT.

Jeswiet, J., \& Hauschild, M. (2005). EcoDesign and future environmental impacts. Materials and Design, 26, 629-34.

Julier, G. (2017). Economies of design. London: Sage Publications.

Malinowski, B. (1976). Introdução: tema, método e objetivo desta pesquisa. In B. Malinowski (Ed.), Os argonautas do Pacífico Ocidental: um relato do empreendimento e da aventura dos nativos nos arquipélagos da Nova Guine Melanesia (Coleção Os Pensadores, pp. 17-34). São Paulo: Abril Cultural.

Manzini, E. (2007). Design, social innovation and sustainable ways of living: creative communities and diffused social enterprise in the transition towards a sustainable network society. Milano: Politecnico di Milano.

Manzini, E., \& Vezzoli, C. (2005). O desenvolvimento de produtos sustentáveis: os requisitos ambientais dos produtos industriais. São Paulo: Editora da Universidade de São Paulo.

McDonough, W., \& Braungart, M. (2002). Cradle to cradle: remaking the way we make things. New York: North Point Press

Organisation for Economic Co-operation and Development-OECD. (2020). How's life? 2020: measuring well-being. Paris: OECD Publishing. https://doi.org/10.1787/9870c393-en.

Petrina, S. (2000). The political ecology of design and technology education: an inquiry into methods. International Journal of Technology and Design Education, 10, 207-237.

Prahalad, C. K. (2005). A riqueza na base da pirâmide: como erradicar a pobreza com o lucro. São Paulo: Artmed.

Romeiro Filho, E. (2013). Design and craftsmanship: the Brazilian experience. Design Issues, 29(2), 64-74.

Santos, V. S. (2014). A trajetória de desafios, superação e sucesso entre a ASMARE, a Pastoral de Rua de Belo Horizonte e a Prefeitura Municipal de Belo Horizonte. Projeto InterAção, Universidade Federal de Viçosa. Retrieved in 2020, April 24, from http://www.projetointeracao.ufv.br/?informativos=estudo-de-caso-a-trajetoria-de-desafios-superacao-e-sucesso-entre-a-asmare-apastoral-de-rua-de-belo-horizonte-e-a-prefeitura-municipal-de-belo-horizonte

Sen, A. (1999). Development as freedom. Oxford: Oxford University Press.

Sorokin, P. A. (1964). Sociocultural causality, space, time: a study of referential principles of sociology and social science. New York: Russell-Russell.

Souza, C. C., Alves, L. L., \& Romeiro Filho, E. (2019). Sustainability and cleaner production principles in micro furniture companies: two Brazilian cases. Product: Management \& Development, 17(1), 52-58. http://dx.doi.org/10.4322/pmd.2019.007.

Teodoro, N. F. G. (2011). Contribuição para a sustentabilidade na construção civil: reciclagem e reutilização de materiais [Dissertação de Mestrado]. Instituto Superior Técnico de Lisboa, Lisboa.

Thiollent, M. (1983). Problemas de metodologia. In A. C. C. Fleury \& N. Vargas (Eds.), Organização do trabalho: uma abordagem interdisciplinar e sete estudos sobre a realidade brasileira (pp. 54-83). São Paulo: Atlas.

Thiollent, M. (1985). O processo de entrevista. In M. Thiollent (Ed.), Crítica metodológica, investigação social e enquete operária (2. ed., pp. 79-99). São Paulo: Polis.

Thiollent, M. (2007). Metodologia da pesquisa-ação (15. ed.). São Paulo: Cortez. 132 p.

Topcua, E., Altinoz, B., \& Aslanc, A. (2020). Global evidence from the link between economic growth, natural resources, energy consumption, and gross capital formation. Resources Policy, 66, 101622. http://dx.doi.org/10.1016/j.resourpol.2020.101622.

Tukker, A., Emmert, S., Charter, M., Vezzoli, C., Sto, E., Munch Andersen, M., Geerken, T., Tischner, U., \& Lahlou, S. (2008) Fostering change to sustainable consumpition and production: an evidence based view. Journal of Cleaner Production, 16(11), 1218-1225.

Voss, C., Tsikriktsis, N., \& Frohlich, M. (2002). Case research in operations management. International Journal of Operations \& Production Management, 22(2), 195-219.

Walker, S. (2002). A journey in design an exploration of perspectives for sustainability. The Journal of Sustainable Product Design, 2(1-2), 3-10.

Walker, S., \& Dorsa, E. (2001). Making design work: sustainability, product design and social equit. The Journal of Sustainable Product Design, 1, 41-48.

Wisner, A. (1987). Por dentro do trabalho, ergonomia: método e técnica (F. M. Gomide Vezzá, Trans.). São Paulo: FTD Oboré Editorial. Título original: Analyse de la situation de travail, méthodes et critères. 
World Summit on Sustainable Development - WSSD. (2002, August). Global change global opportunity: trends in sustainable development. Johannesburg: United Nations Department of Economic and Social Affairs. Retrieved in 2019, June 13, from http://www.un.org/esa/sustdev/publications/critical_trends_report_2002.pdf

Xavier, A. F., Naveiro, R. M., Aoussat, A., \& Reyes, T. (2017). Systematic literature review of eco-innovation models: opportunities and recommendations for future research. Journal of Cleaner Production, 149, 1278-1302. http://dx.doi.org/10.1016/j.jclepro.2017.02.145.

Yin, R. K. (1994). Case study research: design and methods (2nd ed.). London: Sage Publications.

Zafarmand, S. J., Sugiyama, K., \& Watanabe, M. (2003). Aesthetic and sustainability: the aesthetic attributes promoting product sustainability. The Journal of Sustainable Product Design, 3, 173-186. 